\title{
Audit Committee Mechanism to Improve Corporate Governance: Evidence from a Developing Country
}

\author{
Madan Lal Bhasin \\ Bang College of Business, KIMEP University, Almaty, Republic of Kazakhstan \\ Email: madan.bhasin@rediffmail.com
}

Received June 19, 2012; revised July 22, 2012; accepted August 10, 2012

\begin{abstract}
Nowadays, an audit committee (AC) is being looked upon as a distinct culture for CG and has received a wide-publicity across the globe. Government authorities, regulators and international bodies all have indicated that they view an $\mathrm{AC}$ as a potentially powerful tool that can enhance the reliability and transparency of financial information. Being mandatory under Security Exchange and Board of India (SEBI's) Clause 49 of the Listing Agreement, an AC can be of great help to the board in implementing, monitoring and continuing "good" CG practices to the benefit of the corporation and all its stakeholders. This study performs a "content" analysis on the AC reports of the top 500 listed companies in India during 2005 to 2008 to determine the information content of these reports and the extent to which these reports conform to the Clause 49 requirements of the SEBI. Also, discussed are the various trends about an AC characteristics viz., size, composition, activity, as well as, the extent of non-audit services provided by auditors in the top 500 listed Indian companies. No doubt, it is essential for the Indian corporations to accept and continue with the CG reforms that are "demarcated" by the challenges of the "new" millennium.
\end{abstract}

Keywords: Corporate Governance; Audit Committee; SEBI Clause 49; Sarbanes-Oxley Act; Listing Agreement; Board of Directors; Financial Reporting; India

\section{Introduction}

A corporation is a "congregation" of various stakeholders, namely, customers, employees, investors, vendor-partners, government and society. The relationship between shareholders and corporate managers is fraught with "conflicting" interests that arise due to the separation of ownership and control, divergent management and shareholder objectives, and information "asymmetry" between managers and shareholders. Due to these conflicting interests, managers have the incentives and ability to maximize their own utility at the expense of corporate shareholders. As a result, corporate governance structures evolve that help in mitigating these agency conflicts (Dey 2008) [1]. Simply stated, "Corporate governance (henceforth, CG) is the system by which businesses are directed and controlled." In fact, CG deals with conducting the affairs of a corporation in such a way that there is "fairness" to all stakeholders and that its actions benefit the "greatest" number of stakeholders. $\mathrm{CG}$ is the acceptance by management of the inalienable rights of shareholders as the "true" owners of the corporation, and of their own role as "trustees" on behalf of the shareholders. This has become imperative in today's globalized business world where corporations need to access "global" pools of capital, need to attract and retain the "best" human capital from various parts of the world, need to "partner" with vendors on mega collaborations, and finally, need to live in "harmony" with the community.

CG is beyond the realm of law; it stems from the culture and mindset of management and cannot be regulated by legislation alone (Cohen et al., 2008) [2]. Corporations, therefore, need to recognize that their growth requires the cooperation of all the stakeholders; and such cooperation is enhanced by the corporation adhering to the "best" CG practices. In this regard, the management needs to act as "trustees" of the shareholders at large and prevent "asymmetry" of information and benefits between various sections of shareholders, especially between the owner-managers and the rest of the shareholders. While large profits can be made taking advantage of the asymmetry between stakeholders in the short-run, balancing the interests of all stakeholders alone will ensure survival and growth in the long-run. Thus, CG is a key element in improving the economic "efficiency" of a firm. Indeed, corporations pool capital from a large investor base, both in the "domestic" and in the "international" capital markets. In this context, "investment is ultimately an act of faith in the ability of a corporation's 
management." In this regard, investors expect management to act in their best interests at all times and adopt good CG practices. The failure to implement "good" governance can have a "heavy" cost beyond regulatory problems. Evidence suggests that corporations that do not employ meaningful governance procedures can pay a significant risk premium when competing for scarce capital in the public markets (Aguilera et al., 2009) [3].

During the last two decades, an "audit committee" (henceforth, AC) has become a very common "mechanism" of CG internationally. An AC is expected to monitor the reliability of the corporation's accounting and auditing processes in order to protect shareholder interests (Agoglia et al., 2011) [4] and prevent attempts to manipulate earnings numbers (Klein, 2002) [5]. Also, an AC serves as a mechanism to hold "external" auditors accountable for the scope, nature and quality of their work (Dignam, 2007) [6]. The duties of an AC often include recommending the appointment of external auditors, reviewing the corporation's financial statements, taking action on items and concerns raised by the auditors, mediating between the auditor and management, and advising on any significant findings in the external and internal audit investigations (Caskey et al., 2010) [7]. According to Beasley et al., (2009) [8], "An AC is increasingly responsible for the quality of financial reporting and oversight of the audit processes in large public companies." In 2002, the United States enacted the Sarbanes-Oxley (SOX) Act, requiring that all US publicly traded companies establish an "independent" AC. Despite immediate public criticism of SOX's AC requirements, there has been a noticeable increase in the number of countries now "mandating" their use. When SOX was signed into law, only 10 of the world's 40 largest capital markets had mandatory AC requirements. A significant number of countries amended their laws, regulations, or listing rules over the next $7-8$ years to require that their own listed corporations establish an AC. As Fichtner (2010) [9] concludes: "In total, 31 of the world's 40 largest capital markets now mandate that certain categories of listed corporations utilize an AC," as shown in Table 1.

The AC function has evolved in India over the years with recommendations of the Confederation of Indian Industries (CII), Kumaramanglam Birla Committee, new rules of the Securities and Exchange Board of (SEBI) and Company Law. Now-a-days, an AC is viewed as an "oversight function of $\mathrm{CG}$, financial reporting process, internal control structure, and audit functions." Government authorities, regulators and international bodies (for example, IOSCO and the OECD) have indicated that they view an $\mathrm{AC}$ as a potentially powerful tool that can enhance the reliability and transparency of financial information (UNCTAD, 2006) [10]. The SOX Act, 2002
Table 1. Audit committee requirements for the 40 largest capital markets.

\begin{tabular}{|c|c|}
\hline $\begin{array}{c}\text { Capital Markets with “Mandatory" } \\
\text { AC Requirements and Date of } \\
\text { Implementation }\end{array}$ & $\begin{array}{l}\text { Capital Markets with } \\
\text { "No Mandatory” } \\
\text { AC Requirements } \\
\end{array}$ \\
\hline 1) Canada (1975) & 1) Brazil \\
\hline 2) Nigeria (1990) & 2) Iran \\
\hline 3) Hong Kong (1999) & 3) Ireland \\
\hline 4) Thailand (1999) & 4) Italy \\
\hline 5) India (2000) & 5) Japan \\
\hline 6) Indonesia (2000) & 6) Norway \\
\hline 7) Korea (2000) & 7) Saudi Arabia \\
\hline 8) Mexico (2001) & 8) Switzerland \\
\hline 9) Argentina (2001) & 9) Venezuela \\
\hline \multicolumn{2}{|l|}{ 10) United States (Sarbanes-Oxley, 2002) } \\
\hline \multicolumn{2}{|l|}{ 11) Spain (2002) } \\
\hline \multicolumn{2}{|l|}{ 12) Turkey (2002) } \\
\hline \multicolumn{2}{|l|}{ 13) Australia (2004) } \\
\hline \multicolumn{2}{|l|}{ 14) Colombia (2005) } \\
\hline \multicolumn{2}{|l|}{ 15) Austria (2006) } \\
\hline \multicolumn{2}{|l|}{ 16) Portugal (2006) } \\
\hline \multicolumn{2}{|l|}{ 17) South Africa (2006) } \\
\hline 18) Russia (2007) & \\
\hline 19) Finland (2008) & \\
\hline
\end{tabular}

20) France (2008)

21) The Netherlands (2008)

22) Romania (2008)

23) Sweden (2008)

24) United Kingdom (2008)

25) Belgium (2009)

26) China (2009)

27) Czech Republic (2009)

28) Denmark (2009)

29) Germany (2009)

30) Greece (2009)

31) Poland (2009)

Source: J. R. Fichtner, "The Recent International Growth of Mandatory Audit Committee Requirements," International Journal of Disclosure and Governance, Vol. 7, No. 3, 2010, p. 234. 
has expanded the formal responsibilities of an AC. The status of an $\mathrm{AC}$ report has evolved from non-existence to voluntarily and now mandatory for publicly traded companies under the SEBI and Companies Act jurisdiction in India. Therefore, this paper seeks to "contribute to our understanding of the value and potential of an $\mathrm{AC}$ as a CG mechanism in a developing country like India." It seeks to examine the structure and functions that are currently performed by an AC in the Indian corporate world.

\section{Literature Review}

Both, an AC and auditor "independence" have been important areas of research in the accounting literature. In the past, various studies on an AC have focused on the independence, activity and on the financial expertise of an AC member. Recently, the research on auditor independence have focused on the extent of "non-audit" services provided by the "external" auditor as well auditfirm tenure, both of which are generally seen as "hindrances" to auditor independence. In fact, renewed interest on CG and an AC have emerged in light of the "new" regulations that were enacted in the wake of the major corporate "scandals", and the consequent enactment of the SEBI's Clause 49 in India and SOX regulations in the US and in other parts of the world.

A significant number of researchers, primarily from the Western and European countries, have studied various dimensions of an AC and its "effectiveness". These studies have led to a lively debate as to the proper composition of the membership of an AC. For example, Romano (2005) [11] argues that an AC composed solely of independent directors, or even a majority of independent directors, do not limit the occurrence of accounting "improprieties", while Prentice and Space (2007) [12] refutes this argument by citing numerous studies confirming that an "independent" AC improves the financial reporting.

Despite the continuing "hot" debate as to whether "independent" directors are a necessary component of an $\mathrm{AC}$, an overwhelming number of studies establish that the mere formation of an AC results in substantial benefits. For example, Knapp (1987) [13] concluded that an AC can improve auditing because "an AC member tend to support auditor, rather than management, when audit disputes occur." On the other hand, Beattie (2007) [14] in his research found that the presence of an AC is a very significant factor in enhancing the third-party perceptions of auditor independence. However, Wild (1996) [15] found evidence that establishment of an $\mathrm{AC}$ enhances earnings quality, and Goodwin-Stewart and Kent (2006) [16] found that an AC is associated with "higher-quality" audits. Similarly, De Fond et al., (2005) [17] study revealed that "over-statements of earnings are less likely among firms that have an AC," while Dechow et al., (1996) [18] study found that "corporations manipulating earnings are more likely to have boards of directors dominated by managers and less likely to have an AC." Williams and Tower (2004) [19], however, conducted a comprehensive simultaneous analysis of the association between five $\mathrm{AC}$ composition and operational characteristics features and earnings management based on a sample of 485 Singapore publicly traded organizations.

Moreover, in a study undertaken by McMullen (1996) [20], the author concluded that "firms with an AC are associated with fewer shareholder lawsuits alleging fraud, fewer quarterly earnings restatements, fewer SEC enforcement actions, fewer illegal acts and fewer instances of audit turnover when there is an audit-client disagreement." By and large, while a vast majority of the studies conclude that an AC provides substantial benefits to the corporation, a handful of studies question their "true" value. In particular, Beasley (1996) [21] study disputes whether an AC actually reduces the likelihood of fraud. Likewise, in a study of an AC in Spain, Pucheta-Martinez and de Fuentes (2007) [22] determined that "the mere presence of an $\mathrm{AC}$ does not reduce the occurrence of error and non-compliance qualifications." However, the same study also determined that other factors, such as the size and independence of an AC did have a significant impact on certain aspects of financial reporting.

Unfortunately, very little research work has been done, both in India and abroad, on the role of an AC in improving CG. For example, Al-Mudhaki and Joshi (2004) [23] examined the composition, focus and functions of an $\mathrm{AC}$ and the effects of the meetings and the criteria used in the selection of members by the Indian listed corporations based on 73 "questionnaire" responses in 2002. Similarly, Agarwal (2006) [24] stated that "an AC of the board is today seen as a key fulcrum of any corporation. Being mandatory under Clause 49, an AC can be of great help to the board in implementing, monitoring and continuing good CG practices to the benefit of the corporation and its stakeholders." Moreover, Cohen et al., (2010) [25] expressed that CG issues have grown more salient in the light of the alleged corporate accounting scandals. Sandra (2005) [26] conclude by saying that "comprehensive regulatory changes, brought on by recent CG reforms, have broadly redefined and reemphasized the roles and responsibilities of all the participants (especially the AC) in a public corporation's financial reporting process."

Researchers recently have deepened the study of governance and auditing outcomes with more recent evidence on auditor selection and retention, findings that governance characteristics influence auditors' risk assessments and planning decisions, some conflicting results related to governance and auditor fees (audit and 
non-audit), and evidence that internal audit budgets are associated with governance characteristics (Carcello et al., 2011) [27]. Other recent insights include the importance of an AC accounting expertise over broader financial expertise; the apparent potential for an AC compensation methods to influence an AC member judgments; the existence of substantive, ceremonial, and informal $\mathrm{AC}$ processes; a deeper understanding of an AC member evaluation of accounting disagreements and adjustments; and the serious consequences to directors when a company experiences accounting trouble.

Over the past two decades, the CG literature in accounting and auditing has grown rapidly. In the present study, our CG focus is primarily on the various "dimensions" of an AC. Documented evidence on effectiveness of an AC in enhancing "good" CG has focused on various aspects, but the issue of interest in this study is the support of an AC in enhancing "auditor" independence. Hinzpeter et al., (2009) [28], for example, found that "an $\mathrm{AC}$ is more likely to support across members of an AC. This is true regardless of whether the member is in a full-time (or part-time) position, such as corporate managers, academicians, and retired partners of certified public accounting firms." Similarly, Pearson (1980) [29], and Dockweiler et al., (1986) [30] showed that "an auditor's reliance on management is reduced due to the direct communication with an AC." However, Lam (2000) [31] found that "the appearance of independence of an $\mathrm{AC}$ would enhance auditor independence and improve transparency in financial reporting." Beattie et al., (1999) [32] also reported that "audit partners, finance directors, and financial journalists believed that an $\mathrm{AC}$ with independent non-executive directors strongly encourages auditor independence. Independent directors of an AC are expected to increase the quality of monitoring because they are not associated with the corporation either as an officers or employees; thus, they would act as the shareholder's watchdog." Similarly, Raghunandan and Rama (2007) [33] revealed that "an AC that consists of quailfied independent directors is better able to contribute towards auditor independence." To sum up, the extant literature provides "strong" empirical support that both an independent AC and higher-levels of audit independence have a significant beneficial effect on enhancing the quality of disclosures, in reducing discretionary earnings management, increasing the informativeness of earnings, and in general enhancing the value of the firm.

From the above description, it is amply clear that India (being a developing country) presents an ideal case for the analysis of improving $\mathrm{CG}$ through making an effecttive use of an AC practices followed by the corporatesector because the economy has been undergoing rapid economic transformation in the financial services, tourism, information-technology sectors, and the "niche" manufacturing gaining momentum too. In the Indiancontext, there has been very limited number of AC studies, as compared to its Western and European counterparts. However, just two studies are available on the theme of an AC in India, which were done by Al-Mudhaki and Joshi and Agarwal, as stated above. The foregoing discussion suggests that the literature on the determinants of an AC disclosure in the Indian $\mathrm{CG}$ context is very "limited and inconclusive". Thus, our present study builds on the previous literature of an AC practice and overall CG scenario in the Indian corporate-sector. The scope of this study has been confined to top 500 Indian "listed" corporations, and a "content" analysis was performed on their annual reports for four years, namely, 2005-06 and 2008-09 respectively. The present study also contributes to the literature in an important sense that it analyzes data from a developing country and an emerging capital market, which has not been widely studied before on the role of an $\mathrm{AC}$ in the context of $\mathrm{CG}$ requirements.

\section{Corporate Governance and Audit Committee Initiatives in India: An Overview}

During the last two decades, an AC has become a common "mechanism" of CG internationally. Originally, "non-mandatory" structures used by a "minority" of corporations, more recently numerous "official" professsional and regulatory committees in many countries have recommended their more "universal" adoption and have advocated "expanded" roles for an AC. Often, increased attention on CG is a result of "financial" crisis. For instance, the Asian financial crisis brought the subject of CG to the "surface" in Asian countries. To quote Lin et al., (2009) [34], "Recent scandals disturbed the otherwise placid and complacent corporate landscape in the US. These scandals, in a sense, proved to be serendipitous. They spawned a new set of initiatives in CG in the US, and triggered a fresh debate in the European Union, as well as, in the Asian countries." Long renowned for their opaque business practices, Asian corporations have undergone a dramatic transformation on the $\mathrm{CG}$ front. Jamie Allen (2008) [35], for example, states that "most of the countries/markets in the Asian region had taken the initiative long-back in 1990s by formulating and implementing an official code of CG," which is summarized in Table 2 .

Beginning in the late $1990 \mathrm{~s}$, the Indian government started implementing a significant "overhaul" of the country's CG system. As described by Afsharipour (2009) [36], "These CG reforms were aimed at making boards and $\mathrm{AC}$ more independent, powerful and focused monitors of management, as well as, aiding shareholders, in- 
Table 2. Development of CG codes in the Asian countries.

\begin{tabular}{cccc}
\hline Country & Date of Main Code(s) & $\begin{array}{c}\text { Are Independent } \\
\text { Director's required? }\end{array}$ & $\begin{array}{c}\text { Are Audit Committees } \\
\text { Required? }\end{array}$ \\
\hline China & $2002 / 2005$ & Yes & Yes \\
Hong Kong & $1993 / 2004$ & Yes & Yes \\
India & $1999 / 2005 / 2007$ & Yes & Yes \\
Indonesia & $2001 / 2006$ & Yes & Yes \\
Japan & $2003 / 2004$ & Optional & Optional \\
South Korea & $1999 / 2003$ & Yes & Yes (Large Firms) \\
Malaysia & $2001 / 2007$ & Yes & Yes \\
Philippines & 2002 & Yes & Yes \\
Singapore & $2001 / 2005$ & Yes & Yes \\
Taiwan & 2002 & Yes (Certain Firms) & Yes (Certain Firms) \\
Thailand & $1999 / 2006$ & Yes & Yes \\
\hline
\end{tabular}

Source: Jamie allen, Asian Corporate Governance Association: Corporate Governance Seminar, Organized by Chubb Insurance and Solidarity, Bahrain, 16 April 2008, p. 10.

cluding institutional and foreign investors, in monitoring management." There have been several leading CG initiatives launched in India since the mid-1990s. The first was by the Confederation of Indian Industry (CII), which came up with the first "voluntary" code of CG in 1998 (www.ciionline.org). In 1996, the CII took a special initiative on CG-the first institutional initiative in Indian industry. In April 1998, the country produced the first substantial code of best practice on CG after the start of the Asian financial crisis in mid-1997. Titled "Desirable Corporate Governance: A Code", this document was written not by the government, but by the CII (1997) [37]. It is one of the few codes in Asia that explicitly discusses domestic CG problems and seeks to apply best-practice ideas to their solution. In the late 1999 , a governmentappointed committee, under the leadership of Kumar Mangalam Birla (Chairman, Aditya Birla Group), released a draft of India's first "national" formal code on CG for listed companies. The committee's recommendations (many of which were "mandatory") were closely aligned to the international "best" practices on $\mathrm{CG}$-and set "higher" standards than most other parts of the region at that time. However, the code was approved by the Securities and Exchange Board of India (SEBI) in early 2000, and was implemented in stages over the following two years (applying first to "newly" listed and "large" companies). It also led to changes in the BSE and NSE stock exchange listing rules.

The next move was also by the SEBI, now enshrined as Clause 49 (very similar to US Sarbanes-Oxley Act, 2002) of the listing agreement. The Naresh Chandra Committee and Narayana Murthy Committee reports followed it in 2002. Based on some of the recommenda- tion of these two committees, SEBI revised Clause 49 of the listing agreement in August 2003. The SOX has received mixed (and increasingly "negative") response in the US. However, Clause 49 and SOX share "similarities but different responses by market." Perhaps, only some CG changes valuable and some CG changes positive in one environment and not others (Balasubramanian et al., 2008) [38]. Also, genesis of changes differs: Clause 49 was introduced by "industry" initiative in India, but SOX was introduced in US due to Enron like scandals. While SEBI proceeded to adopt considerable CG reforms, the implementation and enforcement of such reforms in fact, have lagged behind.

Reform of "central" public-sector enterprises (CPSEs) is also high on the Indian government's agenda. Strong PSEs would be better prepared to enter the capital market to raise funds, which means practices must be in place to ensure accountability. The push by the government has resulted in some guidelines, which were issued by the Department of Public Enterprises (2007) [39] (www. dpe.nic.in) in June. Even though these guidelines are voluntary, all CPSEs (both listed and non-listed) are meant to follow them, with compliance of these guidelines to be referred to in the Directors' report, Annual report and the chairman's speech during the Annual General Meeting. The Department will grade the corporations on the basis of their compliance with the guidelines. Issued on an experimental basis for a year, they will be revised "in the light of experience gained". Thus, in CG practices, India can be proud of what it has achieved so far, initially voluntarily and later under guidance of various regulators, while recognizing that obviously much more needs to be done. 


\section{Audit Committee Mechanism in India}

There has been growing recognition in recent years of the importance of CG in ensuring sound financial reporting and deterring fraud. The audit serves acts as a monitoring device and is thus, part of the CG mosaic (Kaushik, 2009) [40]. It is claimed that the auditing system in India is "comprehensive and well supported by law, which ensures that impartiality, objectivity and independence of statutory auditors are maintained" (Giridharan, 2004) [41]. However, experience has shown that certain weaknesses and lacunae do exist in the Indian system. In this context, Ganguly (2001) [42] asserts, "Various types of accounting manipulations, irregularities and leakages go unnoticed to the detriment of the public and shareholders." However, over the years, this arrangement was felt inadequate in view of the changing business scenario and it is felt that a greater interaction and link between the auditors and the top echelon of management is needed.

The series of accounting "scandals" have intensified "pressure" from the stakeholders and the regulators on an $\mathrm{AC}$ to do the jobs, for which they were hired. Even though most corporations have an $\mathrm{AC}$, "their role has been limited due to the lack of expertise and time." An "active" AC is important because it indicate the commitment to the issues of interest because of the reports it release about the activities undertaken during the financial year and the efforts made to ensure adequate internal control (Chatterjee, 2011) [43]. In addition, an AC must be given the role to approve and review audit fees, thus neutralizing the bias of management influence on the negotiations with the auditors. Of equal importance, auditor "independence" can be safeguarded if an AC is composed of a majority of independent and non-executive directors and this might indicate that their independent status would contribute to auditor independence through bridging communication networks and neutralizing any conflict between the management and the auditor (Puri et al., 2010) [44]. Indeed, an AC can go a long-way in "enhancing the credibility of the financial disclosures of a corporation and promoting transparency." Thus, it is essential for the Indian corporations to accept and continue with the reforms that are "demarcated" by the challenges of the "new" millennium.

\subsection{Legal Framework for an Audit Committee}

Public corporations in India face a "fragmented" regulatory structure. The Companies Act, 1956 is administered by the Ministry of Corporate Affairs (MCA) and is currently enforced by the Company Law Board (CLB). The MCA, the SEBI, and the stock exchanges jointly share jurisdiction over the "listed" corporations, with the MCA being the "primary" government body charged with administering the Companies Act, while SEBI has served as the securities market "regulator" since 1992. Likewise the CG standards in the US and the UK, India's CG reforms followed a "fiduciary and agency cost model." With a focus on the agency model of CG, the Clause 49 reforms included detailed rules regarding the role and structure of the corporate board and internal control systems.

An AC has been prescribed as a part of CG mechanism to be followed by the "listed" corporations, under clause 49 of the Listing Agreement, and by certain "public" corporations under the Companies Act, 1956. Nowa-days, an AC is an important tool to consider and decide on all financial parameters and policies, internal controls, review of auditing, project implementation, reconstructtion, merger and amalgamation, and any financial irregularities. It is noteworthy to know "how the constitution of an AC generally takes place and the so called directors being members of an $\mathrm{AC}$ are really independent and discharge their fiduciary duties entirely in an unbiased and unobtrusive manner."

\subsubsection{The Indian Companies Act, 1956}

Section 292A was inserted in the Companies Act, 1956 with effect from December 13, 2000, providing that "every public corporation having a paid-up capital of not less than Rs. 5 crore shall constitute a committee of the board of directors known as an AC." Further, it provides an $\mathrm{AC}$ should have discussions with the auditors periodically about internal control systems, the scope of audit including the observations of the auditors and review of half-yearly and annual financial statements before submission to the board, and also ensure compliance of internal control systems. The supremacy of an AC is recognized in the manner that recommendations of an $\mathrm{AC}$ on any matter relating to financial management including audit report shall be binding on the board and, if the board does not accept the recommendations of an $\mathrm{AC}$, it shall record the reasons therefore, and communicate such reasons to the shareholders. In the event of default of the provisions of Section 292A, the corporation and every officer in default shall be punishable with imprisonment for a term up to one year or with fine up to Rs. 50,000 or with both. The offence is compoundable under section $621 \mathrm{~A}$ of the Act. A non-banking financial corporation (NBFC) having assets of Rs. 50 crore and above as per its last audited balance sheet is required to constitute an $\mathrm{AC}$, consisting of not less than 3 members of its Board of Directors. The AC constituted by an NBFC under section 292A of the Companies Act, 1956 shall be the AC for this purpose.

\subsubsection{SEBI Clause 49 of Listing Agreement}

Based on the recommendations of the Committee headed by Mr. Kumarmangalam Birla on CG in "listed" corpo- 
rations, the SEBI amended the Listing Agreement on February 21, 2000 by providing therein Clause 49 on CG. On October 29, 2004a "revised" Clause 49 was introduced, which was finally made effective from December 31,2005 . All existing listed-corporations having a paidup share capital of Rs. 3 crore and above or net worth of Rs. 25 crore or more at any time in the history of the corporation, have to comply with the same. The corporations seeking listing for the "first" time have to comply at the time of seeking "in-principle" approval for such listing. The clause 49 provides for appointment of independent directors, $\mathrm{AC}$ and several other parameters for disclosure to and for protection of interest of shareholders.

\section{Research Methodology}

Annual reports are an ideal place to apply an AC framework because they allow us to compare AC positions and trends across different corporations, industries and countries. They are an instrument for "communicating issues comprehensively and concisely, and they are produced regularly, so they can be used to analyze management attitudes and policies across reporting periods."

The main objective of the present research study is "to survey the prevailing practices of an AC disclosure made by the corporate-sector in India over a four year period from 2005-06 to 2008-09." Accordingly, the sample-size of this study consists of top-500 listed corporations from India in terms of their market capitalization, as on March 31,2008 . The annual reports and other relevant information of the selected corporations were obtained from the two databases, first one provided by SANSCO - Annual Reports Library Services (www.sansco.net), and second by Directors Database - a CG initiative of Bombay Stock Exchange prepared in association with Prime Database (www.directorsdatabase.com).

Reports on the AC were subjected to a "content" analysis to identify the title and format of such reports. The content analysis of annual reports involves "codification" of qualitative and quantitative information into "pre-defined" categories in order to derive "patterns" in the presentation and reporting of information. The "coding" process also involved reading the annual report of each corporation and coding the AC information according to pre-defined categories. Over the last decade, content analysis has been used by several leading researchers to study the performance and reporting (Beattie, 2007) [14]. Therefore, as part of the present study, "content" analysis has been used to analyze the extent of an $\mathrm{AC}$ disclosures made by the top 500 listed companies in India. By looking at the disclosures made within their annual reports, one can examine the extent to which Indian corporations "publicly" document the presence (or im- portance) of an AC. Specifically, the paper covers the following aspects related to an audit committee: 1) The structure and composition of an AC; 2) The criteria used to select an AC members; 3) Examining the importance of functions currently performed by an $\mathrm{AC}$ and also to analyze any differences in the practices of corporations in this regard; 4) The areas of an AC review focus; and 5) The effects of meetings on an AC functions. Finally, as part of this study, an attempt will be made to examine and analyze the trends about various characteristics of an $\mathrm{AC}$, such as, their size, composition and activity, as well as, extent of non-audit services provided by the auditors in the top 500 listed Indian corporations.

\section{Findings of Study and Analysis of Results}

The SEBI's Clause 49 (2004) [45] and other regulatory changes have put tremendous demands on an AC. Having the right directors on an $\mathrm{AC}$-with mandated independence and financial literacy combined with integrity, healthy skepticism and judgment, knowledge of the corporation and industry, and the courage to challenge decisions - is an important driver of an AC "effectiveness". The AC members must learn "how to work smarter and to allow enough time to complete their ever-lengthening list of duties." In fact, given their "pumped-up" workload, they are struggling to know what to put at the top of the list. As Heffes (2007) [46] lucidly puts it: "The AC has a lot on their plates and so they need help to ensure they see the forest, not just the trees. While they should review information carefully and challenge management when necessary; they should not be resolving everyday issues or making management decisions."

This section presents detailed trends about various characteristics of an $\mathrm{AC}$, such as, their size, composition and activity, as well as, extent of non-audit services provided by the auditors in the Indian corporations. These trends are presented for the top 500 listed corporations in India, based on their market capitalization as on March 31,2008 , for four years covering the financial years 2005-06 to 2008-09. As stated earlier under the research methodology, all the required annual reports and other secondary sources of information in respect of the top 500 listed corporations were outsourced and extracted from the private database maintained by SANSCO services (www.sansco.net) and Directors Database (www. directorsdatabase.com). Moreover, Tables 3-8 are constructed based on the disclosures made in the "Corporate Governance Reports" filed by these corporations. In fact, the year 2006 marks the year when all the listed firms were required to comply with the revised provisions of the SEBI's Listing Clause 49, which were first notified on October 29, 2004 but came into effect from January 1, 2006. Table 3 summarizes distribution of corporations 
Table 3. Distribution of corporations according to size of audit committee.

\begin{tabular}{ccccc}
\hline Size of Audit Committee (AC) & $\mathbf{2 0 0 5 - 0 6}$ & $\mathbf{2 0 0 6 - 0 7}$ & $\mathbf{2 0 0 7 - 0 8}$ & $\mathbf{2 0 0 8 - 0 9}$ \\
\hline 2 & 0.30 & 2.19 & 0.51 & 1.25 \\
3 & 57.19 & 50.27 & 51.39 & 49.87 \\
4 & 29.64 & 33.61 & 34.43 & 36.84 \\
5 & 7.78 & 9.02 & 9.87 & 8.02 \\
6 & 2.99 & 3.83 & 3.04 & 3.26 \\
7 & 2.10 & 0.55 & 0.51 & 0.50 \\
8 & 0.00 & 0.27 & 0.00 & 0.25 \\
9 & 0.00 & 0.27 & 0.25 & 0.00 \\
Average Size of AC & $\mathbf{3 . 6 2}$ & $\mathbf{3 . 6 6}$ & $\mathbf{3 . 6 6}$ & $\mathbf{3 . 6 2}$ \\
No. of Corporations & $\mathbf{3 3 4}$ & $\mathbf{3 3 6}$ & $\mathbf{3 9 5}$ & $\mathbf{3 9 9}$ \\
\hline
\end{tabular}

Source: Annual Reports of Top 500 Listed Corporations in India, SANSCO.

according to size of an AC.

According to Carcello et al., (2002) [47], "The AC plays an important role overseeing and monitoring the financial reporting process, internal controls, and the external audit. They provide a communication bridge between management and the internal and external auditors." No doubt, to maintain integrity of their monitoring functions, an $\mathrm{AC}$ is required to perform their responsebilities "diligently". As per Clause 49, "A qualified and independent $\mathrm{AC}$ shall be set up. The $\mathrm{AC}$ shall have minimum three directors as members. Two-thirds of the members of AC shall be independent directors." Judged in the context of Clause 49 regulations requiring listed corporations to have an AC with a minimum of 3 members, Table 3 shows that nearly all (98.75 percent) corporations have complied with this regulation. However, a large majority of the corporations have already constituted their $\mathrm{AC}$, with the minimum size required under the regulations; however, with one-third (36.84) of the corporations adding one "extra" member. In fact, there are very few Indian corporations (just 4 percent) that have an AC with more than 5 members in 2008-09.

In fact, an $\mathrm{AC}$ has been formed to act both as a "conduit" of information supplied by the management to the auditors, and at the same time to "insulate" the auditor from the pulls and pressures of the management (Sharma, 2007) [48]. An AC is, therefore, required to be "independent" of the management and has the "key" responsebility of deciding the scope of work, including the fixation of audit fees and the determination of the extent of non-audit services. As Sarkar and Sarkar (2010) [49] very aptly pointed out, "The basic idea is to make the auditor not to be dependent on "inside" management, both in terms of discharge of its functions as well as in terms of its survival." Tables $\mathbf{5}$ and $\mathbf{6}$ summarize the trends regarding a AC independence in the Indian corporate-sector. Recalling that Clause 49 require an $\mathrm{AC}$ to have at least 2 to 3 of its members as "independent" directors, Table 4 shows that the "mean" of independent directors to be 79 over these four years from 2005-06 to 2008-09. Surprisingly, 15.32 percent of the Indian listed corporations did not comply with Clause 49 regulations in 2006. However, by and large, corporations in India seem to be making a serious effort to comply with the regulations, with the extent of non-compliance signifycantly decreasing from 15.32 percent in 2006-07 to 10.35 percent in 2008-09.

A striking observation with regard to independence of an $\mathrm{AC}$ is "the steady decline in the percentage of corporations with fully independent AC." While during 200506 more than half of the corporations (54.98) had "voluntarily" chosen to have a fully independent $\mathrm{AC}$, this percentage has steadily declined, surprisingly, to just over one-third (37.88) by 2008-09. What is instead observed is a very steady move to have an AC, which are just in accordance with the minimum independence requirement that is prescribed under the law. Given the size distribution of an $\mathrm{AC}$, a fraction between $2 / 3$ and less than 1 implies a "mandatory" compliance under the Clause 49 regulations.

This is further borne out by the steady "increase" in the proportion of corporations that have an "executive" (or management) director present in an AC from 2006 to 2008. Recall that until 2006, when the revised Clause 49 came into effect, an AC was required to consist only of non-executive directors, with majority of them being independent. The revised Clause 49, shockingly removed the non-executive director requirement and instead specified that an AC to have a minimum of three members, with two-thirds of them being independent. Given 
Table 4. Trends in audit committee independence: distribution of corporations.

\begin{tabular}{ccccc}
\hline \multirow{2}{*}{ Fraction of Independent Directors } & \multicolumn{3}{c}{ Year } \\
\cline { 2 - 5 } & $\mathbf{2 0 0 5}$ & $\mathbf{2 0 0 6}$ & $\mathbf{2 0 0 7}$ & $\mathbf{2 0 0 8}$ \\
\hline $\mathrm{f}<2 / 3$ & 8.16 & 15.32 & 12.76 & 10.35 \\
$2 / 3 \leq \mathrm{f}<3 / 4$ & 18.43 & 18.11 & 22.45 & 23.48 \\
$3 / 4 \leq \mathrm{f}<1$ & 18.43 & 22.84 & 25.51 & 28.28 \\
$\mathrm{f}=1$ & 54.98 & 43.73 & 39.29 & 37.88 \\
No. of Corporations & $\mathbf{3 3 4}$ & $\mathbf{3 6 6}$ & $\mathbf{3 9 5}$ & $\mathbf{3 9 9}$ \\
Fraction of Independent Directors (ID) & $\mathbf{0 . 8 5}$ & $\mathbf{0 . 7 8}$ & $\mathbf{0 . 7 8}$ & $\mathbf{0 . 7 9}$ \\
Fraction with Managing Director (MD) in the & $\mathbf{1 9 . 5 1}$ & $\mathbf{1 9 . 7 0}$ & $\mathbf{1 9 . 9 0}$ & $\mathbf{2 2 . 4 7}$ \\
Audit Committee (AC) (\%) & & & &
\end{tabular}

Source: Annual reports of top 500 listed corporations in India, SANSCO.

the specification of a minimum size of three, however, the move from the majority to two-thirds rule did not impose any extra independence burden. The only effect of the revised Clause 49 regulations was that "management directors could now be part of an AC." Unfortunately, what we observe since then is a change in $\mathrm{AC}$ composition that seems to be a direct response to the change in the regulation. The steady decline in fully independent $\mathrm{AC}$ is also consistent with this change in regulation, as non-executive directors are more likely to be also "independent" directors. Moreover, "non-executive" directors could be "independent" directors, or "gray" directors. "Gray" directors are those who are related to the executive directors or have a financial interest in the corporation. It should be noted that corporations belonging to "business groups very often have family members serving as "gray" directors on corporation boards."

After the CG scandals of early 2000, policy-makers all around the world have responded by creating "codes" to improve "ethical" standards in business. A common theme in these guidelines is the "independence of the boards of directors that oversee corporate managers." For example, in 2002, the NYSE and NASDAQ submitted proposals that required boards to have a majority of independent directors with no material relationships with the corporation (Magilke et al., 2009) [50]. An "independent" director is defined as someone who has never worked at the corporation or any of its subsidiaries or consultants, is not related to any of the key employees, and does not/did not work for a major supplier or customer. The rationale for this "policy" recommendation is that board members with close business relationships with the corporation or personal ties with high-ranking officers may not assess its performance dispassionately, or may have vested interests in some business practices. To quote Ravina and Sapienza (2009) [51], "Some criti- cize the emphasis on independent board members, claiming that while they are independent in their scrutiny, they have much less information than insiders. If the executives want to act against the interest of the shareholders, they can simply leave outsiders in the dark. Thus, since the independent board members have very limited information, their monitoring could be extremely ineffective."

Table 5 describe the "fraction" of independent directors on the AC of corporations in India as a measure of $\mathrm{AC}$ independence, and how this has changed over the 4 years time period from 2005-2009 for the Indian corporations. This is shown for corporations with different sizes of audit corporations, where the size is $3,4,5$, or 6 . The trends in independence presented in Table 5 for different sizes of AC confirms that "the decline in fully independent $\mathrm{AC}$ is true for of all sizes, though the decline is more pronounced for an $\mathrm{AC}$ which is bigger in size." Unfortunately, the bigger-size AC has higher "non-compliance" with the Clause 49 requirements. For example, in 2008, almost one-third (31.25) of the AC with size of 5 did not have the requisite number of independent directors required under Clause 49.

Undoubtedly, an AC plays a "vital" role in ensuring the independence of the audit process. In a recent study conducted by Sharma et al., (2011) [52], the author concludes as: "This study is the first to demonstrate that an $\mathrm{AC}$ can moderate threats to auditor independence thus, protecting the quality of financial reporting." To maintain integrity of their monitoring function, an $\mathrm{AC}$ is required to perform their responsibilities "diligently". Because diligence is extremely difficult to observe directly, research uses an AC meeting "frequency" as a proxy for diligence (Raghunandan and Rama, 2007) [37]. Prior research by Vineeta Sharma et al., (2009) [53], however, focuses on the consequences of an AC meetings and very clearly demonstrates "greater" meeting frequency is usu- 
ally associated with a "reduced" incidence of financial reporting problems, and "greater" external audit quality. SEBI's Clause 49 requires the AC "to have, at least, 4 meetings per year with not more than four months of gap between two successive meetings." Accordingly, Table 6 (shown below) presents the distribution of corporations according to the number of meetings held. It can be very clearly observed that "there is a steady improvement in compliance with this requirement; only 6.28 percent of the corporations holding less than 4 meetings in 200809." Moreover, the "average" number of meetings held is nearly five (4.82) in the last two years, namely 2007-08 and 2008-09 respectively. It appears that many corporations are "more" frequently holding their meetings, as per their individual requirements, and were not simply following the "dictates" of the law.

As per the "spirit" of the SEBI's listing requirements, an $\mathrm{AC}$ needs to meet at appropriate times throughout the year, thus, ensuring that they have enough time to discuss various issues fully. While AC meetings are "occurring more frequently and for longer periods, chairs should ensure the $\mathrm{AC}$ has time to reflect on issues and not just

Table 5. Trends in audit committee independence: distribution of corporations.

\begin{tabular}{ccccccccc}
\hline \multirow{2}{*}{$\begin{array}{c}\text { Fraction of Independent } \\
\text { Directors }\end{array}$} & \multicolumn{3}{c}{ Size $=\mathbf{3}$} & \multicolumn{5}{c}{ Size = 4 } \\
\cline { 2 - 9 } $\mathrm{f}<2 / 3$ & $\mathbf{2 0 0 5}$ & $\mathbf{2 0 0 6}$ & $\mathbf{2 0 0 7}$ & $\mathbf{2 0 0 8}$ & $\mathbf{2 0 0 5}$ & $\mathbf{2 0 0 6}$ & $\mathbf{2 0 0 7}$ & $\mathbf{2 0 0 8}$ \\
\hline 2.41 & 7.73 & 8.50 & 6.53 & 6.06 & 15.97 & 10.29 & 9.72 \\
$3 / 4 \leq \mathrm{f}<3 / 4$ & 28.04 & 32.04 & 39.50 & 42.21 & 0.00 & 0.00 & 0.00 & 0.00 \\
$\mathrm{f}=1$ & 0.00 & 0.00 & 0.00 & 0.00 & 48.48 & 52.10 & 61.76 & 62.50 \\
No. of Firms & 64.55 & 60.22 & 52.00 & 51.26 & 45.45 & 31.39 & 27.94 & 27.78 \\
& $\mathbf{1 8 9}$ & $\mathbf{1 8 1}$ & $\mathbf{2 0 0}$ & $\mathbf{1 9 9}$ & $\mathbf{9 9}$ & $\mathbf{1 1 9}$ & $\mathbf{1 3 6}$ & $\mathbf{1 4 4}$ \\
\hline & $\mathbf{2 0 0 5}$ & $\mathbf{2 0 0 6}$ & $\mathbf{2 0 0 7}$ & $\mathbf{2 0 0 8}$ & $\mathbf{2 0 0 5}$ & $\mathbf{2 0 0 6}$ & $\mathbf{2 0 0 7}$ & $\mathbf{2 0 0 8}$ \\
\hline $\mathrm{f}<2 / 3$ & 23.08 & 30.30 & 38.46 & 31.25 & 11.11 & 28.57 & 16.67 & 15.38 \\
$2 / 3 \leq \mathrm{f}<3 / 4$ & 0.00 & 0.00 & 0.00 & 0.00 & 33.33 & 35.71 & 58.33 & 61.54 \\
$3 / 4 \leq \mathrm{f}<1$ & 50.00 & 51.52 & 38.46 & 59.38 & 0.00 & 21.43 & 8.33 & 15.38 \\
$\mathrm{f}=1$ & 26.92 & 18.18 & 23.08 & 9.38 & 55.56 & 14.29 & 16.67 & 7.69 \\
No. of Firms & $\mathbf{2 6}$ & $\mathbf{3 3}$ & $\mathbf{3 9}$ & $\mathbf{3 2}$ & $\mathbf{9}$ & $\mathbf{1 4}$ & $\mathbf{1 2}$ & $\mathbf{1 3}$ \\
\hline
\end{tabular}

Source: Annual reports of top 500 listed corporations in India, SANSCO.

Table 6. Meetings held by an audit committee (AC)—distribution of corporations.

\begin{tabular}{ccccc}
\hline \multirow{2}{*}{ No. of Meetings Held } & \multicolumn{3}{c}{ Year } \\
\cline { 2 - 5 } & $\mathbf{2 0 0 5}$ & $\mathbf{2 0 0 6}$ & $\mathbf{2 0 0 7}$ & $\mathbf{2 0 0 8}$ \\
\hline 0 & 0.93 & 0.56 & 1.03 & 0.50 \\
1 & 0.62 & 3.36 & 1.28 & 0.25 \\
2 & 2.17 & 1.96 & 1.28 & 1.01 \\
4 & 11.46 & 6.16 & 3.59 & 4.52 \\
5 & 39.94 & 43.14 & 44.10 & 45.23 \\
6 & 24.46 & 23.81 & 25.13 & 26.88 \\
7 & 9.91 & 11.48 & 12.31 & 11.31 \\
Average No. of Meetings Held & 10.53 & 9.52 & 11.28 & 10.30 \\
Number of Corporations & $\mathbf{4 . 6 7}$ & $\mathbf{4 . 6 2}$ & $\mathbf{4 . 8 3}$ & $\mathbf{4 . 8 2}$ \\
\hline
\end{tabular}

Source: Annual reports of top 500 listed corporations in India, SANSCO. 
comply with legal requirements." Undoubtedly, an important issue with respect to meetings is the "duration" of the AC meeting, and the "preparation-time" that is given to the AC members to have "meaningful" discussions about the financial operation of the corporations. For instance, FICCI and Thornton (2009) [54] conducted a CG review of 500 mid-sized Indian corporations which show that "in 50 percent of the corporations $\mathrm{AC}$ meetings lasted for less than two hours, while in only 9 percent of the corporations did the meetings went beyond four hours. The majority of the corporations gave an "average" preparation time of up to 7 days to the $\mathrm{AC}$ members in terms of mailing them the agenda of the meetings, while only 6 percent gave time of more than two weeks."

An important dimension of an AC "effectiveness" that has gained the attention of regulators and academics is the "financial expertise" of the AC members. However, both the SOX and SEBI's Clause 49 mandates the disclosure of whether or not an AC includes a "financial" expert. However, the operationalization of who is a financial expert was and still is a controversial issue. For example, Krishnan and Visvanathan (2008) [55] have argued that effective $\mathrm{AC}$ members are those who have "general management" experience rather than those who have an "accounting or financial" background. The SEC, initially, proposed a "narrow" definition to include only accounting financial experts - that is, directors with experience as a CPA, auditor, CFO, controller, or chief accounting officer. However, subsequently the SEC defined financial expert "broadly" to include non-accounting financial experts, such as directors with experience as a CEO or president. Was the SEC correct in defining financial experts to include both accounting and non- accounting experts? Because an $\mathrm{AC}$ is the ultimate "monitor" of the financial reporting process, an AC financial expertise is a key determinant of its "effectiveness". However, Krishnan and Lee (2009) [56] in another study found that "firms with higher litigation-risk are more likely to have an accounting financial expert on their AC. This association occurs for firms with relatively strong governance but not for those with weak governance."

Additional characteristics of an AC for the 500 toplisted corporations in India are presented in Table $\mathbf{7}$ for the financial year 2008-09, which presents key measures of AC "quality" that have been the focus of reform initiatives. Among these are: 1) the presence of members with accounting degree; 2) the number of directorships held by an independent director; 3 ) the tenure of the independent director; and 4) the mean age of independent director serving on the AC. While an AC independence is of paramount importance for ensuring the integrity of the financial reporting process, there is a growing recognition that "what is perhaps more important is the financial literacy and commitment of the $\mathrm{AC}$ members to discharge the various functions entrusted to them by the law."

As Dhaliwal et al., (2010) [57] succinctly puts it: "While SOX proposes a "narrow" definition of financial expertise, to include individuals with experience in accounting or auditing, the SEC controversially adopted a "broader" definition of financial expertise that includes accounting and certain types of non-accounting (finance and supervisory) financial expertise." Motivated by the SOX requirement that "public" companies disclose whether they put a financial expert on their AC, we test

Table 7. Audit committee characteristics (sample means): 2008-2009.

\begin{tabular}{lc}
\hline \multicolumn{1}{c}{ Various Characteristics of an Audit Committee } & Mean Score \\
\hline Size of Audit Committee (Nos.) & 3.65 \\
Size of Board of directors (Nos.) & 8.92 \\
Audit Committee has a member with an accounting degree (\%) & 63.00 \\
Board of directors has a member with an accounting degree (\%) & 95.00 \\
Number of Audit Committee members with an accounting degree (Nos.) & 1.35 \\
Number of Board of director members with accounting degree (Nos.) & 2.78 \\
Percentage of Audit Committee members with an accounting degree (\%) & 40.13 \\
Percentage of Board of director members with an accounting degree (\%) & 31.82 \\
Total Number of directorships of independent directors serving in the AC (Nos.) & 2.61 \\
Median tenure of independent directors serving in the Audit Committee (Yrs.) & 6.53 \\
Median age of independent directors serving in the Audit Committee (Yrs.) & 58.29 \\
\hline
\end{tabular}

Source: Annual reports of top 500 listed corporations in India, SANSCO; directors database, Bombay stock exchange. 
whether the market reacts favorably to the appointment of directors with financial expertise to the AC. We find a positive market reaction to the appointment of accounting financial experts assigned to an $\mathrm{AC}$ but no reaction to non-accounting financial experts assigned to $\mathrm{AC}$, consistent with accounting-based financial skills, but not broader financial skills, improving the AC ability to ensure high-quality financial reporting (Firth and Rui, 2007) [58]. According to SEBI's Clause 49, "All members of an $\mathrm{AC}$ shall be financially literate and at least one member shall have accounting or related financial management experience." For example, Bindal (2011) [59] very appropriately pointed out, "While Clause 49 does not require all $\mathrm{AC}$ members to possess accounting degrees, it can be hardly imagined that an $\mathrm{AC}$ will be able to do justice to its role without any of its members having a formal training on the complexity of the accounting process and the various accounting and auditing standards that confront today's corporations." There is no doubt that all "fresh-appointed" AC members need a "robust" orientation-program, allowing them to understand their role and the corporation's financial reporting process, so that they can "add" value to the AC sooner.

In addition, Johnstone et al., (2011) [60] very strongly observes as: "Internal controls have long been recognized as important in ensuring high-quality financial reporting." The AC is formed to regularly review processes and procedures to ensure the effectiveness of internal control systems so that the accuracy and adequacy of the reporting of financial results is maintained at high-level at all times. To discharge their responsibility, it is important for the members of an AC to have "formal" knowledge of accounting and financial management, or experience of interpreting financial statements. The Listing Agreement (Clause 49) requires "all members of an AC shall be financially literate and at least one member shall have accounting or related financial management expertise." Clause 49 , by way of explanation, defined the term "financially" literate as "the ability to read and understand basic financial statements, e.g., balance sheet, profit and loss account and statement of cash flows. Further, a member will be considered to have accounting or related financial management expertise if he/she possesses experience in finance or accounting, or requisite professional certification in accounting, or any other comparable experience or background which results in the individual's financial sophistication, including being or having been a chief executive officer, chief financial officer or other senior officer with financial oversight responsibilities." Unfortunately, the explanations given above are not free from some ambiguity. Table 7 shows that 63 percent (about two-thirds) of the top 500 Indian listed corporations had an $\mathrm{AC}$ with at least one member with an accounting degree. However, where an AC did not have a member with an accounting knowledge, it was very likely the board had one such a member. On an average, 40.13 percent of the AC members had an accounting degree. Similarly, percentage of board members with an accounting degree was 31.82. However, "median" tenure and "age" of independent directors serving in the AC during 2008-09 was 6.63 and 58.29 years, respectively.

Another fundamental condition which needs to be fulfilled by all AC members is their ability to devote "sufficient-time" to effectively discharge all the functions assigned to them by law (Ward, 2009) [61]. For instance, Emmerich et al., (2006) [62] advises as: "To be sure, prospective $\mathrm{AC}$ members must understand that more will be required of them - more time and more efforts - than may have been demanded in the past. It seems clear that all aspects of the "legal" system are likely to place a heavier emphasis on independence and to demand greater attention and involvement (that is, greater commitment) from corporate directors in general, but especially from AC members, than in the past." The legal standards for measuring the independence and the duties of an AC member, by-and-large, have not changed. As we have seen, the current SEC regulations discourage directors with more than three directorships to be members of an AC because "over the commitment that comes with too many directorships might hamper the ability of the directors to dutifully carry out all the functions expected of him/her." In this context, it is encouraging to note from Table 7 that the "average" number of directorships held by the independent directors in the top 500 listed Indian corporations during 2008-09 was 2.61, less than three. This is a welcome development and will hopefully persist in the coming years. In this context, Zabihollah et al., (2003) [63] states: "Having the right directors on the AC-with mandated independence and financial literacy combined with integrity, healthy skepticism, knowledge of the corporation and industry, and the courage to challenge decisions - is an important driver of AC effectiveness."

In the past, some Western researchers have examined the relation between CG characteristics and the audit fees. Strong governance could increase the demand for auditing (thereby increasing fees) and/or reduce auditors' assessments of risk (thereby reducing fees). For example, Krishnan and Visvanathan (2009) [55] in their study found that "audit fees are negatively associated with accounting expertise on the AC but only in corporations with strong governance. Audit fees increase with board size, board meetings, AC meetings, and CEO duality. Also, the relation between audit fees and $\mathrm{AC}$ accounting expertise is negative, when earnings management risk is low, but positive when the earnings management risk is high." Thus, an AC with accounting experts appears to 
demand more "extensive" auditing when "risk" is higher. Conversely, research by Lassila et al., (2010) [64] finds that "the use of the auditor for tax services is positively related to CG strength - composite of board size, board independence, audit committee size, audit committee independence, shareholders' rights, and institutional ownership."

Now, moving over to issues relating to auditor independence and non-audit fees, Table 8 presents some relevant statistics for the top 500 Indian listed corporations for two years, viz., 2006-07 and 2007-08. It can be observed that in 80 and 79.40 percent of the corporations in 2006-07 and 2007-08 respectively, the statutory auditor was also rendering non-audit services. During these two years, there is virtually no significant change. Comparative figures available for the US in 2000, which predates the passage of the SOX Act, shows that out of the 16,700 corporations, which were registered with the SEC, only 4100 (or 25 percent) purchased non-audit services from the external auditor. According to a study conducted by Abbott et al., (2007) [65], "Our results are consistent with firms with independent, active, and expert AC being less likely to outsource routine internal auditing activities to the external auditor. However, the outsourcing of non-routine internal audit activities, such as, special projects and EDP consulting are not negatively related to effective AC."

Indeed, interesting differences surface during 2007-08 when the "aggregate" picture is broken down into "ownership" groups. Two important observations can be made on Table 8. First of all, nearly 85 percent of corporations belonging to "business" groups (either domestic or foreign) buy "non-audit" services from the "statutory" auditor. For the same period, the percent for "standalone" firms, who bought "non-audit" services from the "statutory" auditor was 70.54 (domestic) and 62.96 (foreign), respectively. Secondly, the percentage of "foreign" group corporations buying "non-audit" services shows an "increase" (from 84.21 to 88.24) from 2007 to 2008, while "Indian" standalone corporations exhibit a "decline" from 75.73 to 70.54 percent.

Furthermore, Table 8 also presents the extent of nonaudit fees relative to audit fees earned by auditing firms for top 500 listed Indian corporations. Current regulations require that "non-audit fees not to exceed auditfees." As the data in the table demonstrates, "the extent of non-audit fees in both years was well below the statutory limit." More encouragingly, the extent of non-audit to audit fees has declined for all corporations under study from 46.67 percent in 2006-07 to 35.65 in 2007-08. Decomposition by ownership groups shows that extent of non-audit fees (56.38 percent) to be much higher for foreign corporations than for domestic corporations (34.88 percent) in 2007-08. On an average, the ratio of non-
Table 8. Non-audit services and non-audit fees.

\begin{tabular}{|c|c|c|}
\hline Services rendered by Auditors & 2006-07 & 2007-08 \\
\hline $\begin{array}{l}\text { Corporations where Auditors } \\
\text { rendered Non-audit Services }\end{array}$ & (\%) & (\%) \\
\hline Indian Business Groups & 83.90 & 85.15 \\
\hline Indian Standalone & 75.73 & 70.54 \\
\hline Foreign Business Groups & 84.21 & 88.24 \\
\hline Foreign Standalone & 70.37 & 62.96 \\
\hline All Corporations & 80.00 & 79.40 \\
\hline $\begin{array}{l}\text { Non-audit to Audit Fees by } \\
\text { Ownership Groups (Median) }\end{array}$ & (\%) & (\%) \\
\hline Indian Business Groups & 42.00 & 34.88 \\
\hline Indian Standalone & 39.54 & 26.30 \\
\hline Foreign Business Groups & 53.92 & 56.38 \\
\hline Foreign Standalone & 79.42 & 86.89 \\
\hline All Corporations & 46.67 & 35.65 \\
\hline $\begin{array}{l}\text { Non-audit to Audit Fees by Size } \\
\text { (Median) }\end{array}$ & (\%) & (\%) \\
\hline Small $(<750$ crores $)$ & 48.33 & 35.42 \\
\hline Medium ( $>750$ and $<3400$ crores) & 41.43 & 33.50 \\
\hline Large ( $>3400$ crores) & 55.36 & 44.44 \\
\hline All Corporations & 46.67 & 35.65 \\
\hline
\end{tabular}

Source: Annual reports of top 500 listed corporations in India, SANSCO.

audit to audit fees were 42 percent in 2006-07 compared to 53.92 percent for foreign group corporations and 79.42 percent for foreign standalone corporations. More strikingly, while "domestic" corporation exhibits a decline in the non-audit fee percentage from 42 to 34.88 percent, with the decline being more pronounced for "standalone" corporations (from 39.54 to 26.30 percent), "foreign" corporations exhibit a marginal increase from 53.92 to 56.38 percent. However, there was a sharp increase from 79.42 to 86.89 percent in the case of foreign standalone firms. Furthermore, decomposition with respect to "size" shows that the extent of non-audit fees to be higher (55.36 and 44.44 percent) in the "larger" bigger corporations for both years. However, all corporations, irrespective of their size, showed a significant decline in nonaudit fee from 46.67 to 35.65 percent in 2008 .

To sum up, the above analysis of the empirical trends about an AC, and auditor independence in the context of top 500 listed Indian corporations present a "mixed" picture. We observe an increasing trend in compliance with the Clause 49 regulations; there is a tendency to gravitate to the minimum standards with respect to an AC composition. However, there is a little "voluntary" move to 
compose a "fully" independent AC. Instead, what we observe is "an increasing trend of "inside" management being present in the AC. Compared to this, the trends in auditor independence are better. The data with respect to non-audit services and extent of non-audit fees tend to suggest that domestic standalone corporations, which are also likely to be relatively smaller in size, are very steadily moving towards the notion of auditor independence envisaged under the regulations.

\section{Conclusions}

With the rapidly growing instances of corporate failures and the rising dissatisfaction with the functioning of the corporations gave rise to the need of reassuring the stakeholders. As a result, the emphasis was laid on improving the CG practices across the globe. Post-Satyam scandal in India, however, the investors' confidence in the CG system is VERY low. Undoubtedly, in India the concept of CG has already been embedded in the statutes, viz., Company Act, 1956 and SEBI's Clause 49 of the listing agreement. However, the listing agreement is "a weak instrument, as its penal provisions are not hurting enough." Several "regional" stock exchanges, where a large number of corporations are listed, lack effective organization and skills to monitor effective compliance with $\mathrm{CG}$ requirements as stipulated by SEBI. Moreover, a vast majority of corporations, which are not listed on any of the stock exchanges, will remain outside the purview of SEBI's measures. It is, therefore, desirable that the Companies Act needs to be amended suitably for enforcing "good" CG practices in India. Being "mandatory" under Section 292A of the Company Act, 1956 and Clause 49 of the listing agreement, "an AC can be a facilitator of board to implement, monitor and continue good CG practices for the benefit of the corporation and its stakeholders." Moreover, an AC is empowered to function, on behalf of the board of directors, by assuming an important "oversight" role in the CG intended to protect investors and thereby ensure corporate accountability. Besides, an AC has "oversight" responsibility over the $\mathrm{CG}$, the financial reporting process, internal control structure, internal audit functions, and external audit activities.

Over the past 70 years, the AC concept has grown from a committee designed to nominate and arrange the deal of engagement with the auditor to a committee responsible for overseeing the integrity of the corporation's financial reporting process. As the responsibilities of an AC grew, so did the number of countries "mandating" the use of an AC in corporate boardrooms. No doubt, after the passage of the Sarbanes-Oxley in July of 2002, the number of major capital market countries requiring an AC has more than tripled. Even though the member- ship requirements for an AC vary, it is very clear that the majority of major capital market countries view an AC as a critical component of the financial reporting process.

As part of this research study, we examined top 500 listed corporations in India in terms of market capitalizetion as on March 31, 2008. Accordingly, we summarized the trends about various characteristics of an $\mathrm{AC}$, their size, composition, activity, as well as, the extent of nonaudit services provided by the auditors in the Indian corporation sector from 2005-06 to 2008-09. Results of this study indicate that all corporations examined have adopted AC charters that are published at least once every three years. In addition, an AC should have in their charters the oversight of "disaster" planning. All studied corporations currently include a report of an $\mathrm{AC}$ in their annual report or proxy statement. The majority of an AC composition, structure, meetings, and qualification are in compliance with the requirements of the SEBI and organized stock exchanges. The report of an AC is intended to ensure that financial statements are legitimate, the audit was thorough, and the auditors have no flagrant conflicts of interest that may jeopardize their objectivity, integrity, and independence. It is expected that more effective AC disclosures in conformity with the provisions of the Clause 49 of listing rules and Sarbanes-Oxley Act of 2002 (e.g. charter, report) improve the trust and confidence in $\mathrm{CG}$, the financial reporting process, and audit functions.

However, the above analysis of the empirical trends regarding an $\mathrm{AC}$, and auditor independence presents a "mixed" picture. On the one hand, we observe an "increasing" trend in compliance with the Clause 49 regulations. However, at the very same time, we also observe a tendency to gravitate to the "minimum" standards with respect to an AC composition. Moreover, there is a little "voluntary" move to compose a fully-independent AC. Instead, what we observe is an increasing trend of "inside" management being present in an AC. Compared to this, the trends in auditor independence are far better. The data with respect to non-audit services and extent of non-audit fees tend to suggest that "domestic standalone corporations, which are also likely to be relatively smaller in size, are very steadily moving towards the notion of auditor-corporation independence envisaged under the regulations." Without any hesitation, we personally feel this is a very welcome development on the front of AC and auditor independence in the Indian corporate sector. These results should be of direct interest to policy makers and stock exchange regulators throughout the world, who seek to enhance auditor independence by means of general regulatory change.

Currently auditor independence in India, especially with respect to rendering non-audit services and presence of conflict of interest, is largely dependent on "self- 
regulation". The Companies Act of 1956 has little to offer in this regard. Under the existing regulations, there are many unresolved $C G$ issues with respect to auditor and $\mathrm{AC}$ independence in India. The Companies Bill (2009) has incorporated many of these recommendations. For investors to have confidence in the independence of the auditor, the Bill needs to be enacted quickly into law. However, notwithstanding the passage of the Corporations Bill, some issues that have not been incorporated into the Bill will remain as a matter of concern. Unfortunately, there is a lot of resistance from industry circles for further reforms as evidenced from dropping of the Bill and revision of clause 49 on their demand. If this trend continues, the useful contributions from recent committees and the time spent by their expert members in this regard will not reap any benefits. It is essential for the Indian corporate-sector to accept and continue with the reforms that are demanded by the challenges of the new millennium. If it is operationally difficult to do further modifications to the statutes in the immediate future, then the respective Stock Exchanges should explore the possibility of incorporating these additional standards of independence in their Listing Agreement.

The series of accounting scandals have intensified pressure from stakeholders and regulators on an $\mathrm{AC}$ to do the jobs for which they were hired. Though most corporations have an $\mathrm{AC}$, their role has been "limited" due to "lack of expertise and time." An "active" AC is important because it indicate the commitment to the issues of interest because of the reports it release about the activeties undertaken during the financial year and the efforts made to ensure adequate internal control. Of equal importance, auditor independence can be safeguarded if an $\mathrm{AC}$ were composed of a majority of independent and non-executive directors and this might indicate that their independent status would contribute to auditor independence through bridging communication networks and neutralizing any conflict between the management and the auditor (Cohen et al., 2007) [66]. Thus, an AC "mechanism" can go a long-way in enhancing the credibility of the financial disclosures of a corporation and promoting transparency. Those who do not require an $\mathrm{AC}$ in listed corporations are in a "shrinking" minority. As a result, corporate managers in "developing" countries (like India), who are considering a move into a "larger" capital market will most likely need to establish an $\mathrm{AC}$ before their stock may be traded on a listed market.

To sum up, adequate, relevant and high-quality disclosures are one of the most powerful tools available in the hands of "independent" directors, shareholders, regulators, and outside investors to monitor the performance of a corporation. This is particularly important for an emerging economy like India, where there is "insider" dominance. To this extent, "measures that strengthen auditor independence and enhance the powers, functions, and the independence of an $\mathrm{AC}$ will be crucial in the governance of the Indian corporations." Governance "risk" is a key determinant of market-pricing of "listed" securities. A high perceived "independence quotient" of a corporation's auditing process can be reassuring to outside shareholders that can help reduce the risk premium of raising capital, thereby providing a strong business case for strengthening both an auditor and the AC independence. No doubt, it is essential for the Indian corporations to accept and continue with the CG reforms that are "demarcated" by the challenges of the "new" millennium.

\section{REFERENCES}

[1] A. Dey, "Corporate Governance and Agency Conflicts," Journal of Accounting Research, Vol. 46, No. 5, 2008, pp. 1143-1181.

[2] J. Cohen, G. Krishnamoorthy and A. Wright, "Form versus Substance: The Implications for Auditing Practices and Research of Alternative Perspectives on Corporate Governance," Auditing: A Journal of Practice \& Theory, Vol. 27, No. 2, 2008, pp. 181-198.

[3] R. Aguilera and A. Cuervo-Cazurra, "Codes of Good Governance," Corporate Governance: An International Review, Vol. 17, No. 3, 2009 pp. 376-387. doi:10.1111/j.1467-8683.2009.00737.x

[4] C. P. Agoglia, T. S. Doupnik and G. T. Tsakumis, "Principle-Based versus Rules-Based Accounting Standards: The Influence of Standard Precision and Audit Committee Strength on Financial Reporting Decisions," The Accounting Review, Vol. 86, No. 3, 2011, pp. 747-767. doi:10.2308/accr.00000045

[5] A. Klein, "Audit Committee, Board of Director Characteristics and Earnings Management," Journal of Accounting and Economics, Vol. 33, No. 3, 2002, pp. 375-400. doi:10.1016/S0165-4101(02)00059-9

[6] A. Dignam, "Capturing Corporate Governance: The End of the UK Self-regulating System," International Journal of Disclosure and Governance, Vol. 4, No. 1, 2007, pp. 24-41. doi:10.1057/palgrave.jdg.2050046

[7] J. Caskey, V. Nagar and P. Petacchi, "Reporting Bias with an Audit Committee," The Accounting Review, Vol. 85, No. 2, 2010, pp. 447-481. doi:10.2308/accr.2010.85.2.447

[8] M. Beasley, J. V. Carcello, D. R. Hermanson and T. L. Neal, "The Audit Committee Oversight Process," Contemporary Accounting Research, Vol. 26, No. 1, 2009, pp. 65-122. doi:10.1506/car.26.1.3

[9] J. R. Fichtner, "The Recent International Growth of Mandatory Audit Committee Requirements," International Journal of Disclosure and Governance, Vol. 7, No. 3, 2010, pp. 227-243. doi:10.1057/jdg.2009.29

[10] United Nations Conference on Trade and Development, "Guidance on Good Practices in Corporate Governance Disclosure," New York, 2006.

[11] R. Romano, "The Sarbanes-Oxley Act and the Making of 
Quack Corporate Governance," Yale Law Journal, Vol. 114, No. 7, 2005, pp. 1521-1611.

[12] R. A. Prentice and D. B. Space, "Sarbanes-Oxley as Quack Corporate Governance: How Wise Is the Received Wisdom?" Georgetown Law Journal, Vol. 95, No. 6, 2007, pp. 1843-1909.

[13] M. Knapp, “An Empirical Study of Audit Committee Support for Auditors Involved in Technical Disputes with Client Management," Accounting Review, No. 62, No. 3, 1987, pp. 578-588.

[14] V. Beattie, "Lifting the Lid on the Use of Content Analysis to Investigate Intellectual Capital Disclosures," Accounting Forum, Vol. 31, No. 2, 2007, pp. 129-163. doi:10.1016/j.accfor.2007.02.001

[15] J. J. Wild, "The Audit Committee and Earnings Quality," Journal of Accounting, Auditing and Finance, Vol. 11, No. 2, 1996, pp. 247-276.

[16] J. Goodwin-Stewart and P. Kent, "Relation between External Audit Fees, Audit Committee Characteristics and Internal Audit," Accounting \& Finance, Vol. 46, No. 3, 2006, pp. 387-404. doi:10.1111/j.1467-629X.2006.00174.x

[17] M. L. DeFond, R. N. Hann and X. Hu, "Does the Market Value Financial Expertise on Audit Committees of Boards of Directors?" Journal of Accounting Research, Vol. 43, No. 2, 2005, pp. 153-195. doi:10.1111/j.1475-679x.2005.00166.x

[18] P. Dechow, R. Sloan and A. Sweeney, "Causes and Consequences of Earnings Manipulation: An Analysis of Firms Subject to Enforcement Actions by the SEC," Contemporary Accounting Research, Vol. 13, No. 1, 1996, pp. 1-36. doi:10.1111/j.1911-3846.1996.tb00489.x

[19] S. M. Williams and G. Tower, "Audit Committee Features and Earnings Management: Further Evidence," Conference Proceedings 25th McMaster World Congress, Hamilton, 2004.

[20] D. A. McMullen, "Audit Committee Performance: An Investigation of the Consequences Associated with Audit Committee," Auditing: A Journal of Practice \& Theory, No. 15, 1996, pp. 87-103.

[21] M. Beasley, "An Empirical Analysis of the Relations between the Board of Director Composition and Financial Statement Fraud," Accounting Review, Vol. 71, No. 4, 1996, pp. 443-465.

[22] M. C. Pucheta-Martinez and C. de Fuentes, "The Impact of Audit Committee Characteristics on the Enhancement of the Quality of Financial Reporting: An Empirical Study in the Spanish Context," Corporate Governance: An International Review, Vol. 15, No. 6, 2007, pp. 13941412. doi:10.1111/j.1467-8683.2007.00653.x

[23] J. Al-Mudhaki and P. L. Joshi, "The Role and Functions of Audit Committees in the Indian Corporate Governance: Empirical Findings," International Journal of Auditing, Vol. 8, No. 1, 2004, pp. 33-47. doi:10.1111/j.1099-1123.2004.00215.x

[24] S. Agarwal, "Corporate Governance through Audit Committees," The Chartered Accountant, November, 2006, pp. 733-742.
[25] J. Cohen, G. Krishnamoorthy and A. Wright, "Corporate Governance in the Post-Sarbanes-Oxley Era: Auditors' Experiences," Contemporary Accounting Research, Vol. 27, No. 3, 2010, pp. 751-786. doi:10.1111/j.1911-3846.2010.01026.x

[26] C. S. Vera-Munoz, "Corporate Governance Reforms: Redefined Expectations of Audit Committee Responsibilities and Effectiveness," Journal of Business Ethics, Vol. 62, No. 2, 2005, pp. 115-127. doi:10.1007/s10551-005-0177-5

[27] J. V. Carcello, D. R. Hermanson and Z. S. Ye, "Corporate Governance Research in Accounting and Auditing: Insights, Practice Implications, and Future Research Directions," Auditing: A Journal of Practice \& Theory, Vol. 30, No. 3, 2011, pp. 1-31.

[28] R. Hinzpeter, R. Zimerman and K. Piddo, "Getting the Deal through Corporate Governance," Law Business Research, London, 2009, pp. 43-47.

[29] M. A. Pearson, “A Profile of the 'Big Eight' Independence Position,” Baylor Business Studies, Vol. 11, No. 3, 1980, pp. 7-27.

[30] R. C. Dockweiler, L. A. Nikolai and J. E. Holstein, "The Effect of Audit Committees and Changes in the Code of Ethics on Public Accounting," Proceedings of Midwest Annual Meeting, American Accounting Association, Sarasota, 1986, pp. 45-60.

[31] W. P. Lam, "The Development and Significance of Corporate Audit Committees," The CA Magazine, 2000, pp. 3-40.

[32] V. Beattie, R. Brandt and S. Fearnley, "Perceptions of Auditor Independence: UK Evidence," Journal of International Accounting, Auditing and Taxation, Vol. 8, No. 1, 1999, pp. 67-107. doi:10.1016/S1061-9518(99)00005-1

[33] K. Raghunandan and D. Rama, "Determinants of Audit Committee Diligence," Accounting Horizons, Vol. 21, No. 3, 2007, pp. 265-280. doi:10.2308/acch.2007.21.3.265

[34] J. W. Lin, G. Kang and A. Roline, "The Effects of the Blue Ribbon Committee and the Sarbanes Oxley Act of 2002 on the Characteristics of the Audit Committees and the Board of Directors," Advances in Accounting, Finance and Economics, Vol. 2, No. 1, 2009, pp. 54-70.

[35] J. Allen, "Asian Corporate Governance Association: Corporate Governance Seminar," Organized by Chubb Insurance and Solidarity, Bahrain, 2008, p. 10.

[36] A. Afsharipour, "Corporate Governance Convergence: Lessons from the Indian Experience," Northwestern Journal of International Law \& Business, Vol. 29, No. 2, 2009, pp. 335-402.

[37] Confederation of Indian Industry, "Desirable Corporate Governance: A Code 1997,” 2010, pp. 1-12. www.ciionline. org

[38] B. N. Balasubramanian, B. S. Black and V. S. Khanna, "Firm-Level Corporate Governance in Emerging Markets: A Case Study of India," Northwestern Law \& Eco Research Paper No. 09-14, 2008, pp. 1-50.

[39] Department of Public Enterprises, "Guidelines on Corporate Governance for Central Public Sector Enterprises," 
Government of India, New Delhi, 2007. dpe. nic. in/newsite/gcgcpse. pdf

[40] M. Kaushik, "How Good Are Company Boards?" Business Today, 2009.

[41] P. T. Giridharan, "The Audit Committee: A Global Perspective," The Chartered Accountant, 2004, pp. 621-627.

[42] A. Ganguly, "Provisions of Audit Committees in Companies Act Listing Agreement: Need Re-Look," India Infoline, 2001

www.indiainfoline.com/leggal/feat/prov.html

[43] D. Chatterjee, "Audit Committee Observation/Recommendations versus Practices as a Compliance of Corporate Governance in India," DLSU Business \& Economics Review, Vol. 20, No. 2, 2011, pp. 67-78. doi:10.3860/ber.v20i2.1914

[44] R. Puri, R. Trehan and H. Kakkar, "Corporate Governance through Audit Committee: A Study of the Indian Corporate Sector," The IUP Journal of Corporate Governance, Vol. 9, No. 1-2, 2010, pp. 47-56.

[45] Securities and Exchange Board of India, "Corporate Governance in Listed Corporations: Clause 49 of the Listing Agreement," 2004. http://www. sebi-gov. in/circulars/2004/cfdcir0104. pdf

[46] E. M. Heffes, "Audit Committee to CFO: Can We Talk?" Financial Executive, 2007, pp. 29-32.

[47] J. Carcello, D. Hermanson and T. L. Neal, "Disclosure in Audit Committee Charters and Reports," Accounting Horizons, Vol. 16, No. 4, 2002, pp. 291-304.

[48] D. Sharma, "When Audit Committees Do Not Stack Up?" New Zealand Management, Vol. 54, No. 4, 2007, pp. 1617.

[49] J. Sarkar and S. Sarkar, "Auditor and Audit Committee Independence in India," Working Paper Series under Financial Sector Regulatory Reforms Project at Indira Gandhi Institute of Development Research, 2010.

[50] M. J. Magilke, B. W. Mayhew and J. E. Pike, “Are Independent AC Members Objective?: Experimental Evidence," The Accounting Review, Vol. 84, No. 6, 2009, pp. 1959-1981. doi:10.2308/accr.2009.84.6.1959

[51] E. Ravina and P. Sapienza, "What Do Independent Directors Know?: Evidence from Their Trading," Published by Oxford University Press on Behalf of the Society for Financial Studies, 2009, pp. 962-1003.

[52] V. D. Sharma, D. S. Sharma and U. Ananthanarayanan, "Client Importance and Earnings Management: The Moderating Role of Audit Committees," Auditing: A Journal of Practice \& Theory, Vol. 30, No. 3, 2011, pp. 125-156.

[53] V. Sharma, N. Naiker and B. Lee, "Determinants of Audit Committee Meeting Frequency: Evidence from a Voluntary Governance System," Accounting Horizons, Vol. 23, No. 3, 2009, pp. 245-263. doi:10.2308/acch.2009.23.3.245

[54] FICCI Grand Thornton Report, "Corporate Governance Review 2009: India 101-500 Technical Report". http://www.wcgt.in/html/publications/ficci_gt_cgr.php

[55] G. V. Krishnan and G. Visvanathan, "Does the SOX
Definition of an Accounting Expert Matter?" Contemporary Accounting Research, Vol. 25, No. 3, 2008, pp. 827 857. doi:10.1506/car.25.3.7

[56] J. Krishnan and J. E. Lee, "Audit Committee Financial Expertise, Litigation Risk and Corporate Governance," Auditing: A Journal of Practice \& Theory, Vol. 28, No. 1, 2009, pp. 241-261.

[57] D. Dhaliwal, V. Naiker, and F. Navissi, "The Association between Accruals Quality and the Characteristics of Accounting Experts and Mix of Expertise on Audit Committees," Contemporary Accounting Research, Vol. 27, No. 3, 2010, pp. 787-827. doi:10.1111/j.1911-3846.2010.01027.x

[58] M. Firth and O. Rui, "Voluntary Audit Committee Formation and Agency Costs,", International Journal of Accounting, Auditing and Performance Evaluation, Vol. 4, No. 2, 2007, pp. 142-160. doi:10.1504/IJAAPE.2007.015231

[59] C. M. Bindal, "Audit Committee: Highly Integral to Corporate Governance," Chartered Accountant in Practice, Manupatra Publications, 2011, pp. 1-9.

[60] K. Johnstone, C. Li, and K. H. Rupley, "Changes in Corporate Governance Associated with the Revelation of Internal Control Material Weaknesses and Their Subsequent Remediation," Contemporary Accounting Research, Vol. 28, No. 1, 2011, pp. 331-383. doi:10.1111/j.1911-3846.2010.01037.x

[61] R. D. Ward, "Audit Committee Leaders Face Increasing Workload," Financial Executives International, Morristown, 2009, pp. 28-31.

[62] A. O. Emmerich, G. N. Racz and J. Unger, "Composition of the Audit Committee: Ensuring Members Meet the New Independence and Financial Literacy Rules," International Journal of Disclosure and Governance, Vol. 2 , No. 1, 2005, pp. 67-80.

[63] R. Zabihollah, O. Kingsley and M. George, "Improving Corporate Governance: The Role of Audit Committee Disclosures," Managerial Auditing Journal, Vol. 18, No. 6-7, 2003, pp. 530-537. doi:10.1108/02686900310482669

[64] D. R. Lassila, T. C. Omer, M. K. Shelley and L. M. Smith, "Do Complexity, Governance and Auditor Independence Influence Whether Firms Retain Their Auditors for Tax Services?" Journal of the American Taxation Association, Vol. 32, No. 1, 2010, pp. 1-23. doi:10.2308/jata.2010.32.1.1

[65] L. J. Abbott, S. Parker, G. F. Peters and D. V. Rama, "Corporate Governance, Audit Quality and the SOX Act: Evidence from Internal Audit Outsourcing," The Accounting Review, Vol. 82, No. 4, 2007, pp. 803-835. doi:10.2308/accr.2007.82.4.803

[66] J. Cohen, L. M. Gaynor, G. Krishnamoorthy and A. Wright, "Auditor Communications with the AC and the Board of Directors: Policy Recommendations and Opportunities for Research," Accounting Horizons, Vol. 21, No. 2, 2007, pp. 165-187. $\underline{\text { doi:10.2308/acch.2007.21.2.165 }}$ 